\title{
Biological Manipulation of Blackbrush by Goat Browsing
}

FREDERICK D. PROVENZA, JAMES E. BOWNS, PHILIP J. URNESS, JOHN C. MALECHEK, AND JOHN E. BUTCHER

Domestic goats were used to modify the growth form of blackbrush, a spinescent shrub occurring in nearly monospecific stands on several million hectares of rangeland in the southwestern United States. The objective of this research was to provide data on the responses of blackbrush, goats, and cattle to a biological manipulation program in which winter goat browsing was used to stimulate spring twig production in an attempt to improve fall and winter range for cattle. Goats were stocked at 4 intensities during each winter from 1977 to 1979 . Resultant levels of utilization and spring twig production were determined, with increased utilization leading to increased twig production. Browsing improved the nutritional quality of blackbrush by stimulating twig production, and current season's twigs collected during the winter contained more crude protein (6.5 versus $4.6 \%$ ), phosphorus ( 0.10 versus $0.08 \%$ ) and in vitro digestible dry matter ( 48 versus $38 \%$ ) than did older twigs. Cattle (heifers) browsed blackbrush pastures during October of 1979. Heifers in pastures unbrowsed by goats consumed primarily older twigs while those in previously browsed pastures consumed primarily current season's twigs. No statistically significant differences in weight response were recorded for heifers using pastures that were, or were not, previously browsed. In previously unbrowsed pastures, however, the average heifer consumed 1.9 times more protein supplement than did her counterpart in previously browsed pastures.

Blackbrush (Coleogyne ramosissima) is a densely branched shrub, averaging less than $1 \mathrm{~m}$ in height, that occurs in nearly monospecific stands on several million hectares of rangeland in the southwestern United States (Fig. 1). The terminal twigs of blackbrush branches tend to die back for several centimeters from the tip resulting in a spinescent growth form (Bowns 1973). Death of terminal buds suppresses apical dominance and allows lateral twig development. The result is a compacted, spherical canopy. These factors limit the accessibility to and palatability of blackbrush twigs for most ungulates and, consequently, this species is generally considered poor forage.

Humphrey $(1953,1955)$ considered blackbrush poor forage during spring, summer, and fall for cattle, but fair forage for goats during these seasons. In winter, when other feed was scarce, he rated it as fair forage for cattle. Sampson and Jespersen (1963) rated the species good to poor forage for goats and poor forage for cattle on California rangclands. On southern Utah ranges, the U.S. Forest Service (1937) considered blackbrush fair forage for cattle during the winter, and Bowns and West (1976) considered it fair winter and spring forage for cattle and sheep. Research by Bradley (1965) and Wilson (1967), however, indicated that the shrub is important to desert bighorn sheep, and Leach (1956) found it an important contributor to the winter diets of mule deer. Bowns and West (1976) indicated that the greatest economic use of blackbrush-dominated rangelands in Utah was winter browsing by

\footnotetext{
Provenza, Urness and Malechek are research assistant professor, associate professor and professor, Range Science Department, Utah State University, Logan 84322; Butcher is professor, Animal, Dairy and Veterinary Science, Utah State University; and Bowns is professor, Department of Life Sciences, Southern Utah State College, Cedar City, Utah 84720 .

This report was published with the approval of the Director of the Agricultural Experiment Station as journal paper 2754.
}

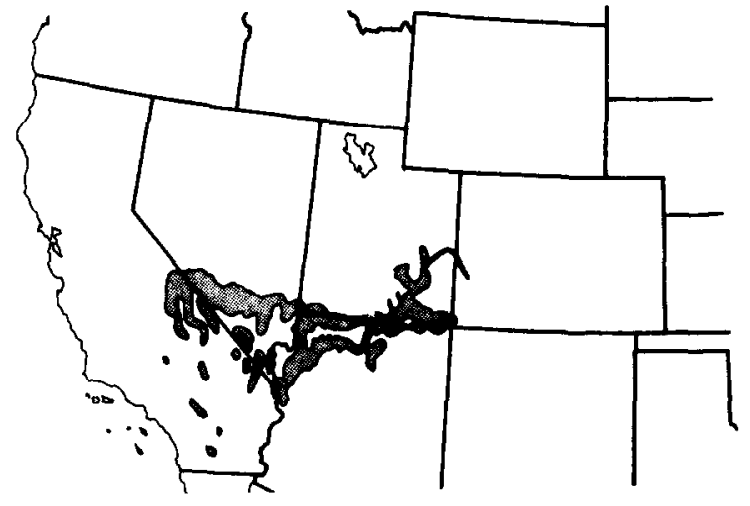

Fig. 1. Map of blackbrush distribution according to Bowns and West (1976).

mule deer and desert bighorn sheep, and winter and spring browsing by livestock.

Nutritionally, blackbrush is low in crude protein and phosphorus. Crude protein levels cited by Bowns and West (1976) for material harvested in February and May were 7.3 and $8.8 \%$ for leaves versus 4.1 and $3.8 \%$ for stems, respectively. The phosphorus contents were 0.11 and $0.14 \%$ for leaves versus 0.10 and $0.13 \%$ for stems, respectively. Intact samples collected during January and February by Provenza (1977) averaged $4.6 \%$ crude protein and $0.16 \%$ phosphorus.

Domestic goats were used to modify the growth form of blackbrush in southwestern Utah in an attempt to increase the productivity and the nutritional value of blackbrush twigs for cattle. The purpose of this paper is to present data on the responses of blackbrush, goats, and cattle.

\section{Methods}

\section{Study Site}

The experiment was conducted on Bureau of Land Management administered land in the extreme southwestern corner of Utah near Gunlock. The study area was at an elevation of $1,280 \mathrm{~m}$ and consisted floristically of blackbrush associated with juniper (Juniperus osteosperma). The soil series of the site was a Pastura Loam with an A-C horizon sequence underlaid by a petrocalcic (caliche) horizon (Bowns 1973). A Bureau of Land Management rain gauge, located approximately $2 \mathrm{~km}$ west of the study area, showed that precipitation averaged $165 \mathrm{~mm}$ from December through June from 1965 to 1976 . An average of $302 \mathrm{~mm}$ of precipitation was recorded during this study, 1977 to 1980.

Physically, the experiment consisted of two blocks (replications) of 8 ha each. Within each block the control and heavily stocked pastures were $1 \mathrm{ha}$, the moderately stocked pasture was $2 \mathrm{ha}$, and the lightly stocked pasture was 4 ha. The browsing periods employed in this study are summarized in Table 1.

\section{Utilization}

Utilization was determined by the method of Provenza and Urness (1981) in which caliper measurements of branch diameters were used to predict the length of twig material present before and after browsing. A branch was that portion of the plant rising from 
Table 1. Browsing periods for the blackbrush study.

\begin{tabular}{lcc}
\hline Class of animal & Year & Browsing period \\
\hline Goat & 1977 & 9 January - 10 March \\
Goat & 1978 & 29 December - 11 March \\
Goat & 1979 & 2 January - 17 March \\
Cattle & 1979 & 1 October - 28 October \\
\hline
\end{tabular}

the ground, and twigs were subdivisions of the branch. Prior to the browsing period, a point on each sample branch was marked with red ink and a caliper measurement made at that point to predict twig material originally available. After the browsing period, each browsed tip distal to the marked point was measured and the amount of twig material removed was estimated. The regression equation used to predict twig lengths from branch diameters was:

natural logarithm length $=4.0398+2.3855$ (natural logarithm diameter)

Percent utilization was computed as follows:

$$
\mathrm{U}=\frac{\sum \mathrm{PT}}{\mathrm{PB}}(100)
$$

where: $\mathrm{U}=$ percent utilization

$\Sigma P T=$ sum of the predicted browsed twig lengths

PB = predicted branch length before browsing

Percent utilization was measured on 2 branches from each sample plant $\left(50 \mathrm{ha}^{-1}\right)$. A terminal branch was selected from older branches growing on the outer edges of the plant, and a basal branch was selected from sprouts and young branches arising from within the terminal branch canopy.

\section{Twig Growth}

Seasonal twig growth was measured on a terminal and basal branch from each sample plant $\left(50 \mathrm{ha}^{-1}\right)$ in September after blackbrush growth ceased (Bowns 1973). Random selection of both branches was assured by placing a circular hoop $0.9 \mathrm{~m}$ in diameter and covered with a $5-\mathrm{cm}$ wire grid over each plant. The grid was supported by a metal stake that allowed it to revolve. The stake was positioned in the center of each sample plant, and the grid was spun and allowed to come to rest. A metal pin was inserted as predetermined points on the grid intersections, and the current season's growth on the terminal or basal branch nearest a pin was measured to the nearest $1 \mathrm{~mm}$.

\section{Nutritional Analyses}

Blackbrush samples, hand-plucked to simulate twigs consumed by goats browsing current season's and older twigs from the terminal branches of plants growing on deep and shallow soils, were analyzed for crude protein, phosphorus, and in vitro drymatter digestibility. Eight plants were sampled within each treatment by soil depth combination, and samples were collected in January of 1978 and March 1979. The statistical design of the experiment was a factorial with twig age and soil depth as the main effects and the experiment was replicated twice (1978 and 1979).
In an additional study, hand-plucked blackbrush samples that simulated twigs consumed by goats browsing current season's terminal versus basal branches were analyzed for crude protein and in vitro dry-matter digestibility. Twigs from the terminal and basal branches of 6 plants were collected in March of 1979. The statistical design of this study was a factorial with 6 replications (plants) of 2 treatments.

Prior to chemical analysis of duplicate samples, twigs were ground through a Wiley mill with a 40-mesh $\mathrm{cm}^{-1}$ screen. Crude protein content was determined by the Kjeldahl method (Horwitz 1970), phosphorus content was determined by the ammonium molybdate-ammonium vanadate method described by Chapman and Pratt (1961), and in vitro dry-matter digestibility was determined by the two-stage method described by Tilley and Terry (1963). Rumen inocula were obtained from a goat that had been browsing blackbrush pastures in 1978, and by stomach pump from 3 esophageally fistulated goats fed alfalfa in 1979.

\section{Cattle Response}

Thirty-two Hereford cattle (yearling heifers) browsed blackbrush pastures from 1 to 28 October 1979. These heifers were placed in a blackbrush holding pasture during the last week in September. On October 1 they were weighed, and 4 animals were randomly assigned to each of the 8 blackbrush pastures. Six of these pastures had been browsed previously by goats, while 2 had not. Diet sample and weight response data were collected at 2-week intervals during the browsing period.

\section{Diets}

Hand-plucked blackbrush samples that duplicated twigs consumed by cattle were collected in the 4 pastures of block one. Within a pasture, each animal was observed during the day and blackbrush plants and plant parts similar to those being consumed were sampled.

Samples were separated into current season's versus older growth and weighed for the botanical analysis. For the chemical analysis, current season's and older twigs were pooled, ground through a Wiley mill with a 40-mesh $\mathrm{cm}^{-1}$ screen, and analyzed in duplicate for crude protein (Horwitz 1970), and in vitro dry-matter digestibility (Tilley and Terry 1963). The statistical design for this experiment was a factorial with repeated measurements. The main effect was stocking rate, and animals were nested within this effect. The experiment was repeated twice during the browsing period.

\section{Weights}

Heifers in all blackbrush pastures had access to $36 \%$ proteinblock supplement during the browsing period. Block consumption was recorded by pasture on a weekly basis. The animals were weighed after 2 and 4 weeks of browing, having been penned overnight without access to feed or water. The statistical design for these studies was a split plot with 2 replications. The whole plot effect was pastures, and the sub-plot effect was dates.

Table 2. Stocking intensities and utilization levels for blackbrush pastures.

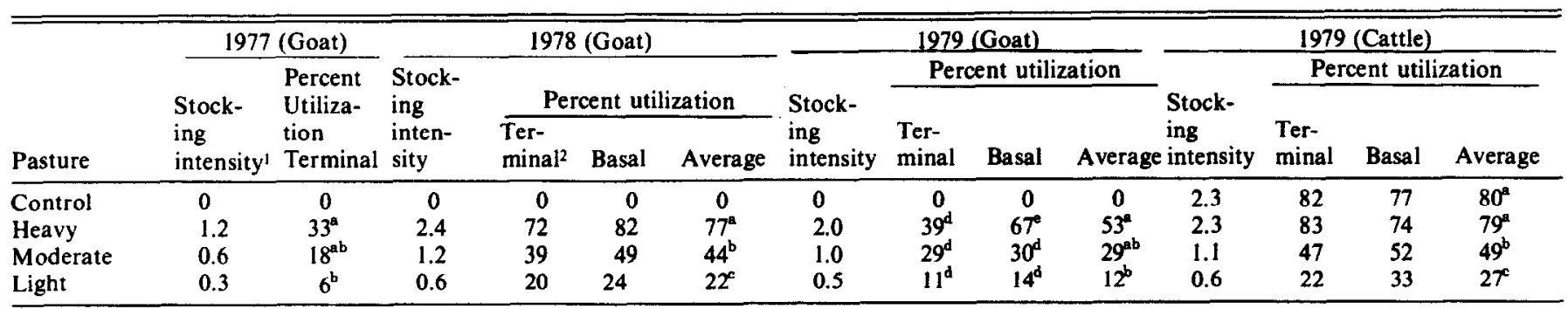

'Animal-unit-months hectare ${ }^{-1}$; animal units for goats and heifers were computed on a weight basis with $454 \mathrm{~kg}$ equal to one animal unit.

${ }^{2}$ Terminal versus basal branches in $1978(P=0.10)$.

abc Means in the same column followed by a different letter are significantly different $(\boldsymbol{P}<0.05)$.

de $\mathrm{Mean}$ in the same row followed by a different letter are significantly different $(P=0.03)$. 
Table 3. Cumulative blackbrush use by goats (2 January to 17 March) and cattle (1 October to 28 October) during 1979.

\begin{tabular}{|c|c|c|c|c|c|}
\hline \multirow[b]{2}{*}{ Pasture } & \multicolumn{2}{|c|}{ Goat } & \multicolumn{2}{|c|}{ Cattle } & \multirow{2}{*}{$\begin{array}{c}\text { Goat and cattle } \\
\text { Stocking intensity' }\end{array}$} \\
\hline & Stocking intensity ${ }^{1}$ & Percent utilization & Stocking intensity ${ }^{l}$ & Percent utilization & \\
\hline Control & 0 & 0 & 2.3 & 80 & 2.3 \\
\hline Heavy & 2.0 & 53 & 2.3 & 79 & 4.3 \\
\hline Moderate & 1.0 & 29 & 1.1 & 49 & 2.1 \\
\hline Light & 0.5 & 12 & 0.6 & 27 & 1.1 \\
\hline
\end{tabular}

IAnimal-unit-months hectare ${ }^{-1}$; animal units for goats and heifers were computed on a weight basis with $454 \mathrm{~kg}$ equal to one animal unit.

\section{Results and Discussion}

\section{Stocking Intensities and Utilization Levels}

Table 2 summarizes stocking intensities and utilization levels for blackbrush pastures during this study. The data in Table 2 not only establish stocking intensities and utilization levels for goats and cattle, but also indicate how the animals utilized blackbrush. At similar stocking intensities, blackbrush utilization by goats (1978) and cattle (1979) was comparable. Basal and terminal branches were used by both goats and cattle, with a trend toward greater use of basal branches. A statistically significant interaction (branch location $\times$ control, heavy versus moderate, light, $P=0.04$ ) existed for the cattle utilization data because cattle tended to consume more basal branches at lighter utilization levels. As utilization levels increased, however, cattle were apparently unable to consume basal branches as completely as goats (e.g., 1978 goats versus 1979 cattle utilization), probably due to their large muzzle. The small size of blackbrush leaves precluded selection for them; rather, the animals consumed leaves with the twigs and leaf stripping was not observed.

Also of importance was the goats' aversion to current season's growth (CSG) on terminal branches, particularly in 1979. Increased utilization levels and ample moisture stimulated spring twig production in 1978. As a result, the terminal and basal twigs available for goats browsing in the heavily stocked pastures in 1979 consisted entirely of CSG. Goats browsing in the heavily stocked pastures during 1979, however, ate relatively little CSG from terminal branches, and nonsystematic observations indicated that terminal branch consumption increased only after basal branch availability was greatly reduced. The decreased palatability of CSG was apparently related to high tannin levels (Provenza and Malechek 1983b). When plants were browsed one year and rested the next year or two, however, a larger quantity of more palatable twig material was available for consumption than when plants were browsed year after year (Provenza et al. 1983). The increased palatability was apparently related to a decrease in astringent tannins as the proportion of current season's (high in tannins) to older (low in tannins) twigs decreased (Provenza and Malechek 1983a). The decrease in astringent tannins as twigs agcd was presumably due to their polymerization with proteins and carbohydrates; the resulting large molecular weight compounds were probably less astringent, which made the older twigs more palatable.

Table 3 is a summary of data presented in Table 2, and is intended to show aggregate grazing capacities for cattle and goats during 1979. Stocking intensities of 4.3 and 2.1 animal-unitmonths $\mathrm{ha}^{-1}$ for the heavy and moderate treatments, respectively, were achieved during a single year from two forage crops (1978, 1979) without evident overuse of the shrub resource. This is remarkable, considering conventionally held beliefs that blackbrush ranges have inherently low grazing capacity. Even the 2.3 animal-unit-month $\mathrm{ha}^{-1}$ stocking intensity on previously unbrowsed (control) pastures was 29 times higher than agency guidelines of 0.08 animal-unit-months ha ${ }^{1}$ (Jenson et al. 1960).

One major consideration in this argument is whether blackbrush plants could withstand, over the long term, heavy winter use by goats followed by heavy fall use by cattle. Results presented by Provenza et al. (1983) showed that plant vigor was not lowered by 4 consecutive years of extremely heavy utilization; however, abovenormal precipitation was recorded in 2 of those years.

\section{Twig Growth}

Differences in production of CSG resulting from goat browsing at various stocking intensities are presented in Table 4 . Heavy stocking intensities generated the greatest twig production. The lack of statistical significance among moderate and light versus control pastures was due to variable goat use of individual plants in the lightly and moderately stocked pastures. This caused individual plant production to vary greatly within treatments, and resulted in significant error variation. The differences in plant production among years were due to large differences in precipitation from December through June. Factors affecting twig growth in blackbrush were discussed by Provenza et al. (1983).

\section{Nutritional Analyses}

Analyses of blackbrush twigs, hand-plucked to simulate material consumed by goats, indicated that the nutrient content and digestibility of CSG on browsed plants was higher than that of older material on unbrowsed plants (Table 5). Further, goats browsing in pastures where plants were composed primarily of current season's twigs lost less weight than goats browsing in pastures where the plants were composed primarily of older twigs (Provenza and Malechek 1983b). Basal branches were higher in crude protein and more digestible than terminal branches. Basal branches had higher leaf:stem ratios and appeared to be less fibrous than terminal branches, which may account for their higher average nutrient contents and digestibilities. Bowns (1973) indicated that blackbrush leaves were higher in crude protein and lower in acid detergent fiber than stems.

Soil depth also affected the nutrient content of blackbrush, but differences were not highly significant (crude protein $P=0.12$, phosphorus $P=0.11$ ) due to the low number (3) of error degrees of freedom. Plants growing on deep soils tended to contain more nutrients than those growing on shallow soils. Perhaps greater soil depth permitted better soil moisture relations, improving nutrient

Table 4. Current season's twig production by blackbrush plants browsed at 4 stocking intensities.

\begin{tabular}{lccc}
\hline \hline & \multicolumn{3}{c}{$\begin{array}{c}\text { Current season's twig production } \\
\left(\mathrm{mm} \cdot \text { branch }^{-1}\right)\end{array}$} \\
\cline { 2 - 4 } & \multicolumn{3}{c}{ Year } \\
\cline { 2 - 4 } & $1977^{1}$ & $1978^{1}$ & $1979 !$ \\
\hline Pasture Control & $85^{\mathrm{a}}$ & $253^{\mathrm{a}}$ & $230^{\mathrm{a}}$ \\
Light & $81^{\mathrm{a}}$ & $362^{\mathrm{a}}$ & $314^{\mathrm{a}}$ \\
Moderate & $84^{\mathrm{a}}$ & $473^{\mathrm{a}}$ & $426^{\mathrm{a}}$ \\
Heavy & $195^{\mathrm{b}}$ & $1005^{\mathrm{b}}$ & $766^{\mathrm{b}}$ \\
Branch Location & & & \\
Terminal & $118^{\mathrm{c}}$ & $648^{\mathrm{c}}$ & $610^{\mathrm{b}}$ \\
Basal & $76^{\mathrm{d}}$ & $264^{\mathrm{d}}$ & $166^{\mathrm{d}}$ \\
\hline
\end{tabular}

${ }_{1}^{1}$ Average annual precipitation for December through June in 1977, 1978, and 1979 was 133,445 , and $335 \mathrm{~mm}$, respectively, compared to an average of $165 \mathrm{~mm}$ from 1965 to 1976.

${ }^{\mathrm{ab}}$ Means in the same column followed by a different letter are significantly different ( $P=0.11,0.07$, and 0.10 , for 1977, 1978, and 1979, respectively).

${ }^{\text {cd }}$ Means in the same column followed by a different letter are significantly different $(P=0.13,0.03$, and 0.01 for 1977,1978 , and 1979 , respectively). 
Table 5. Percent crude protein, phosphorus, and in vitro dry-matter digestibility (IVDMD) for blackbrush twigs.

\begin{tabular}{|c|c|c|c|c|c|c|c|c|}
\hline \multirow[b]{2}{*}{ Assay } & \multicolumn{2}{|c|}{ Twig age } & \multicolumn{2}{|c|}{ Twig location } & \multicolumn{2}{|c|}{ Plant location } & \multicolumn{2}{|c|}{ Year } \\
\hline & $\begin{array}{l}\text { Current } \\
\text { growth }\end{array}$ & $\begin{array}{c}\text { Older } \\
\text { growth }\end{array}$ & Terminal & Basal & $\begin{array}{l}\text { Deep } \\
\text { soils }\end{array}$ & $\begin{array}{c}\text { Shallow } \\
\text { soils }\end{array}$ & $\begin{array}{c}\text { March } \\
1978\end{array}$ & $\begin{array}{c}\text { January } \\
1979\end{array}$ \\
\hline $\begin{array}{l}\text { Crude protein } \\
\text { Phosphorus } \\
\text { IVDMD }\end{array}$ & $\begin{array}{c}6.5^{\mathrm{a}} \\
0.10^{\mathrm{a}} \\
47.7^{\mathrm{a}}\end{array}$ & $\begin{array}{c}4.6^{\mathrm{b}} \\
0.08^{\mathrm{b}} \\
38.2^{\mathrm{b}}\end{array}$ & $\frac{5.7^{a}}{41.1^{n}}$ & $\frac{6.1^{b}}{44.2^{b}}$ & $\begin{array}{c}5.9^{\mathrm{a}} \\
0.10^{\mathrm{a}} \\
42.7^{\mathrm{a}}\end{array}$ & $\begin{array}{c}5.2^{\mathrm{b}} \\
0.08^{\mathrm{b}} \\
43.1^{\mathrm{a}}\end{array}$ & $\begin{array}{c}6.2^{\mathrm{a}} \\
0.11^{\mathrm{a}} \\
44.3^{\mathrm{a}}\end{array}$ & $\begin{array}{c}4.9^{\mathrm{b}} \\
0.08^{\mathrm{b}} \\
41.6^{\mathrm{a}}\end{array}$ \\
\hline
\end{tabular}

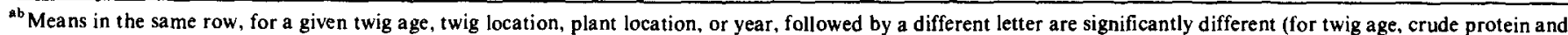

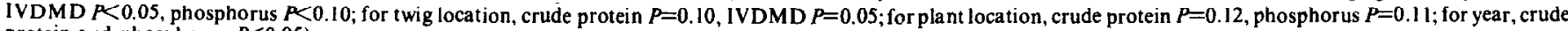
protein and phosphorus $P<0.05$ ).

uptake by the plants. Harner and Harper (1973) stated that improved soil moisture relations enhanced the mineral status of soils by accelerating the microbial action that causes the release of essential elements. Their data showed that soil moisture and the nutrient content of vegetation were closely related. In this connection, Bhaumik and Clark (1947) indicated that decomposer organisms of the soil performed optimally at moisture levels near field capacity if aeration and temperature were favorable, and Moser and Olson (1953) indicated that as soils dry, the activity of soil organisms declines rapidly.

The crude protein and phosphorus contents of twigs collected in March of 1978 were higher than those of twigs collected in January of 1979. The fact that blackbrush generally begins growth in midMarch and was likely then to be in a physiologically active state could account for this result, although blackbrush had not manifested signs of growth at the time these samples were collected.

\section{Cattle Response \\ Diets}

Blackbrush samples, hand-plucked to simulate twigs consumed by cattle, were analyzed for percent CSG (Fig. 2), crude protein (Fig. 3), and IVDMD (Fig. 4). A positive relationship existed between percent CSG and crude protein levels $\left(r^{2}=0.70\right)$, and percent CSG and IVDMD $\left(r^{2}=0.65\right)$. Unaccounted for variability due to plants, twig age, and twig location affected these relationships, lowering the coefficients of determination.

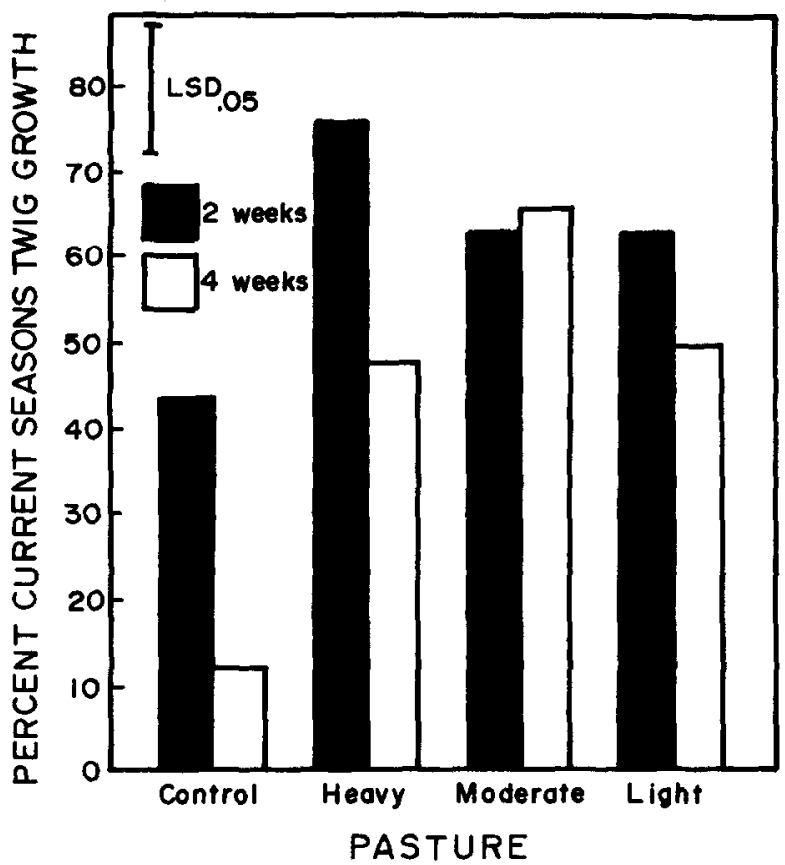

Fig. 2. Percent current season's twig growth in the simulated diets (handplucked) of cattle browsing blackbrush pastures during October, 1979.
Cattle in previously unbrowsed pastures (control) consumed less CSG than cattle in previously browsed pastures (heavy, moderate, light) due to the woody nature of unbrowsed plants. Cattle browsing in the heavily stocked pastures consumed the greatest quantity of CSG. This was a result of the high twig production in those pastures caused by previous goat browsing and abundant moisture during 1979. The percent CSG consumed by cattle browsing in the control and heavily stocked pastures declined during October, however, because of heavy utilization levels (Table 2). The percent CSG consumed by cattle browsing in the moderately and lightly stocked pastures remained constant due to the lower utilization levels. As the percent CSG declined, the levels of crude protein and IVDMD also declined.

\section{Weights}

Cattle browsing in blackbrush pastures were supplemented with $36 \%$ protein blocks. No statistically significant differences in weight responses were recorded for heifers browsing in previously unbrowsed versus previously browsed pastures. The average heifer, however, gained $0.64 \mathrm{~kg} \mathrm{day}^{-1}$ during the first two weeks of the study and lost $0.01 \mathrm{~kg} \mathrm{day}^{-1}$ during the last 2 weeks of the study $(P=0.05)$

Statistically significant differences in consumption of protein block were recorded for heifers in previously browsed versus previously unbrowsed pastures $(P=0.05)$. Animals in previously unbrowsed pastures ate more protein block (Fig. 5). Although block consumption varied among pastures that werc previously browsed, no trends were apparent. Heifers in all pastures increased their consumption of protein block throughout the browsing period. Over the course of the study, the average heifer $(268 \mathrm{~kg})$ in previously browsed versus previously unbrowsed pastures

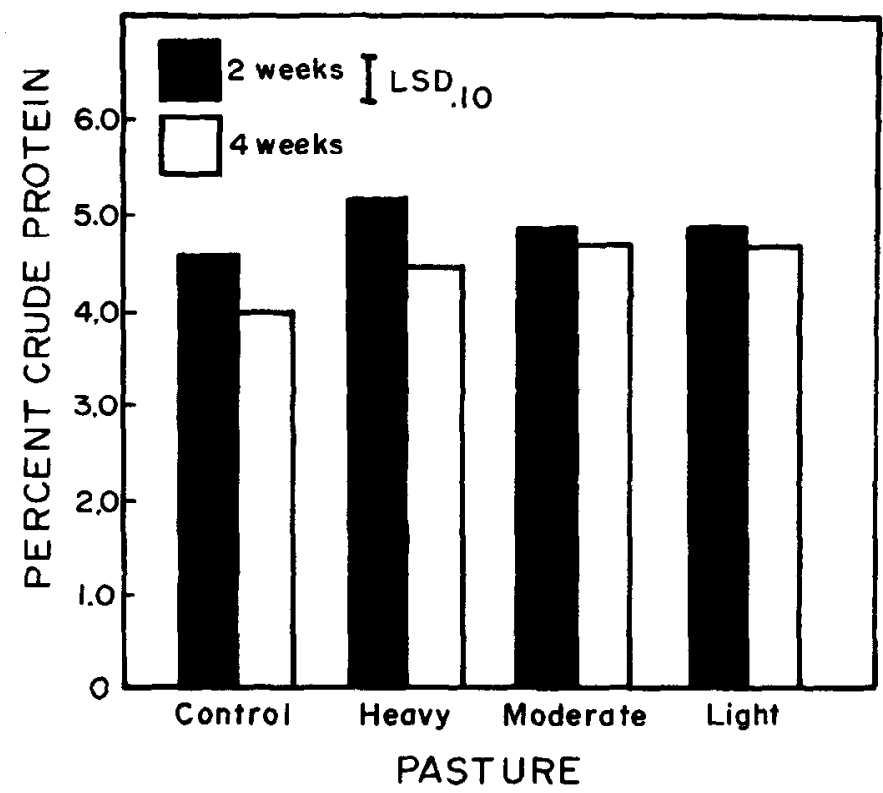

Fig. 3. Percent crude protein in the simulated diets (hand-plucked) of cattle browsing hlackbrush pastures during October, 1979. 


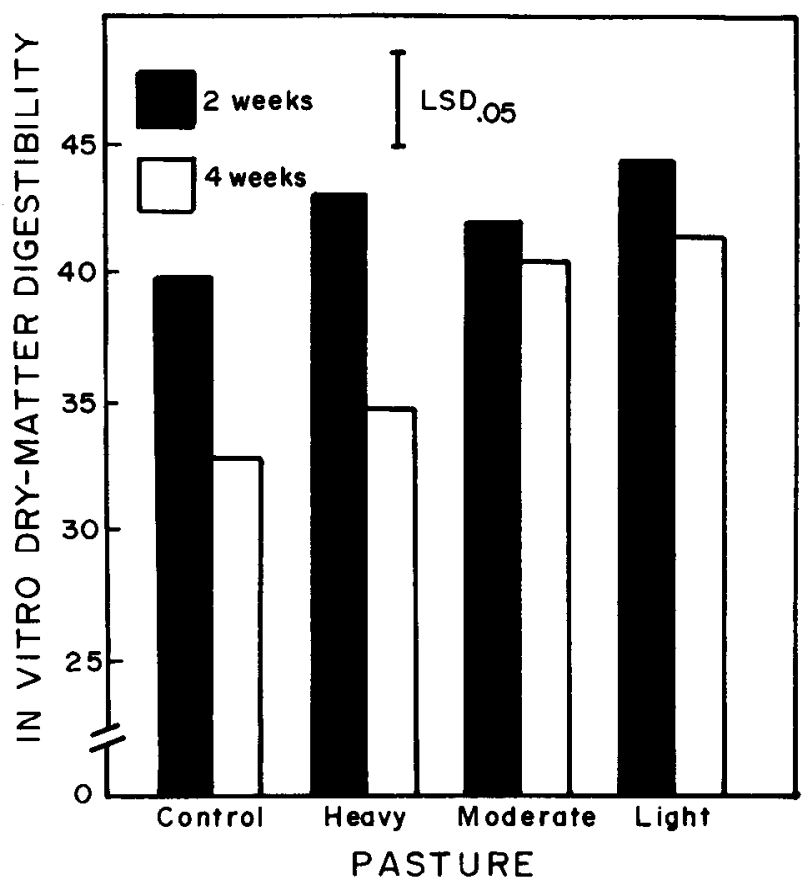

Fig. 4. In vitro dry-matter digestibility of the simulated diets (handplucked) of cattle browsing in blackbrush pastures during October, 1979.

consumed $0.94 \mathrm{~kg}$ versus $1.77 \mathrm{~kg}$ of protein block daily, respectively.

The low crude protein levels and woody nature of twigs in previously unbrowsed pastures probably decreased the digestibility of diets consumed there (Table 5), and may have contributed to the increased consumption of protein block by heifers using those pastures. The assumption is that crude protein levels in the blackbrush diets were low for effective rumen function, and that additional protein from the blocks improved the digestibility and, presumably, intake of the twigs (van Glywsyk 1970, Moir and Harris 1962).

An underlying question regarding differences in protein block consumption is whether heifers in the previously unbrowsed pastures consumed more protein block from hedyphagic (palatability) or euphagic (improved rumen function) motiviation. If increased consumption were due strictly to palatability, cattle browsing in the heavily stocked pastures should have consumed the most protein block because of the low palatability of CSG produced by terminal branches. Instead, heifers in the previously unbrowsed pastures consumed the most protein block, indicating that the response may be physiologically related to intake. Research is needed, however, to provide definitive data.

From a practical standpoint, protein supplementation is required to prevent weight loss in cattle on blackbrush fall and winter range, but some level of weight loss may be acceptable. For example, Pinney et al. (1972) studied the effects of protein supplementation $(60 \%, 120 \%$, and $220 \%$ of recommended allowances) on lifetime production of becf cows. The cows that received the low level of supplementation lived longer and produced more calves of greater weaning weights than did cows that received higher levels of supplementation.

Prior browsing by goats apparently reduced the need for supplementation by increasing the nutrient content and digestibility of blackbrush twigs. Further research is necessary, however, to determine protein supplementation levels for cattle on previously unbrowsed versus browsed blackbrush rangelands.

\section{Conclusions and Recommendations}

Conclusions and recommendations stemming from this research

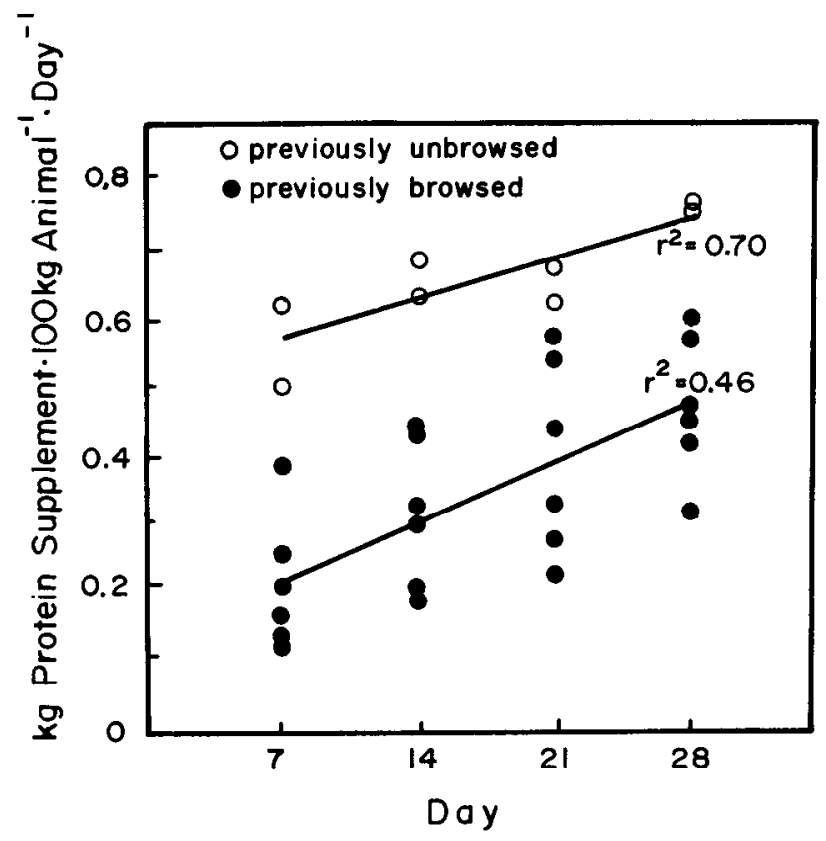

Fig. 5. Quantity of $36 \%$ protein block consumed by cattle browsing in blackhrush pastures during October, 1979.

are:

1. Increase stocking intensities on blackbrush dominated rangelands to about 1.8 animal-unit-months $\mathrm{ha}^{-1}$. This will require more intensive management, with increased fencing and water development. Both types of development are critical to proper use of blackbrush rangelands. Simply increasing (or decreasing) stocking intensities will not improve range use patterns if animals are allowed to water at stream bottoms or other areas where preferred grasses and forbs are more abundant. Blackbrush rangelands are best utilized by forcing intensive browsing of relatively small areas.

2. Browsing systems should be established that employ heavy browsing followed by one or two years rest, depending on blackbrush twig production (Provenza et al. 1983). Rest from browsing allows blackbrush plants to accumulate twigs that are comparatively low in astringent tannins and therefore palatable. The primary purpose of rest is to allow an accumulation of palatable forage for consumption by livestock, rather than to benefit the plants, since blackbrush is apparently capable of withstanding heavy winter twig removal.

3. Animals browsing on blackbrush rangelands should be supplemented with protein to improve rumen function and minimize weight loss. Recommendations on specific timing and a mounts can be made only after further research.

4. Although not currently economically feasible, in the future goats may be used in conjunction with cattle on blackbrush rangelands. For the present, however, properly managed cattle are capable of manipulating and utilizing these rangelands.

\section{Literature Cited}

Bhaumik, H.D., and F.E. Clark. 1947. Soil moisture and microbial activity, Soil Sci. Soc. Proc. 12:234-238.

Bowns, J.E. 1973. An autecological study of blackbrush (Coleogyne ramosissima Torr.) in southwestern Utah. Ph.D. Diss. Utah State Univ., Logan.

Bowns, J.E., and J.E. West. 1976. Blackbrush (Coleogyne ramosissima Torr.) on southwestern Utah rangelands. Utah Agr. Exp. Sta. Res. Rep. 27.

Bradley, W.G. 1965. $\Lambda$ study of the blackbrush plant community on the Desert Game Range. Trans. Desert Bighorn Council 9:56-61. 
Chapman, H.D., and P.F. Pratt. 1961. Methods of analysis of soils, plants, and waters. Univ. California, Riverside.

Harner, R.F., and K.T. Harper. 1973. Mineral composition of grassland species of the eastern great basin in relation to stand productivity. Can. J. Bot. 51:2037-2046.

Horwitz, W., ed. 1970. Official methods of analysis. 1 lth ed. Association of Analytical Chemists. Washington, D.C.

Humphrey, R.R. 1953. Forage production on Arizona rangeland, III, Mohave County. Ariz. Agr. Exp. Sta. Bull. A-34.

Humphrey, R.R. 1955. Forage production on Arizona rangeland, IV, Coconino, Navajo, Apache Counties. Arizona Agr. Exp. Sta. Bull. 266.

Jenson, D.E., M.W. Buzan, and D.E. Dimock. 1960. Bureau of Land Management report of field examinations. Blackbrush burns on Las Vegas grazing district (Nev. 5). Bureau of Land Manage. (Ariz. Strip), St. George, Utah.

Leach, H.R. 1956. Food habits of the Great Basin deer herds of California. California Fish and Game 38:21 1-224.

Moir, R.J., and L.E. Harris. 1962. Ruminal floral studies in the sheep X. Influence of nitrogen intake upon ruminal function. J. Nutr. 77:285-298.

Moser, U.S., and R.V. Olson. 1953. Sulfur oxidation in four soils as influenced by soil moisture tension and sulfer bacteria. Soil Sci. 76:251-257.

Pinney, D.O., D.F. Stephens, and L.S. Pope. 1972. Lifetime effects of winter supplemental feed level and age at first parturition on range beef cows. J. Anim. Sci. 34:1067-1074.
Provenza, F.D. 1977. Biological manipulation of blackbrush (Coleogyne ramosissima Torr.) by browsing with goats. M.S. Thesis. Utah State Univ., Logan, Utah.

Provenza, F.D., J.C. Malechek, P.J. Urness, and J.E. Bowns. 1983. Some factors affecting twig growth in blackbrush. J. Range Manage 35:518520.

Provenza, F.D., and J.C. Malechek. 1983a. Tannin allocation in blackbrush (Coleogyne ramosissima Torr.). Biochem. Syst. and Ecol. 11:

Provenza, F.D., and J.C. Malechek. 1983b. Diet selection by domestic goats in relation to blackbrush twig chemistry. J. Apply. Ecology 20:

Provenza, F.D., and P.J. Umess. 1981. Diameter-length-weight relations for blackbrush (Coleogyne ramosissima) branches. J. Range Manage. $34: 215-217$

Sampson, A.W., and B.S. Jespersen. 1963. California range brushlands and browse plants. Manual 33. Calif. Agr. Exp. Serv.

Tilley, J.M.A., and R.A. Terry. 1963. A two-stage technique for the in vitro digestion of forage crops. J. British Grassl. Soc. 18:104-111.

U.S. Forest Service. 1937. Range plant handbook. U.S. Gov. Printing Office, Washington, D.C.

van Glyswyk, N.O. 1970. The effect of supplementing low-protein hay on the cellulolytic bacteria in the rumen of sheep and on the digestibility of cellulose and hemicellulose. J. Agr. Sci. of Camb. 74:169-180.

Wilson, L.O. 1967. The distribution, ecology, and factors affecting the desert bighorn sheep of southeastern Utah. M.S. Thesis. Utah State Univ., Logan. 